\title{
THE IMPROVEMENT OF EXPERIMENTAL SKILLS BY IMPLEMENTING PREDICT, OBSERVE, EXPLAIN (POE) LEARNING MODEL IN LEARNING SCIENCE
}

\section{Linda Pradina Candra, Peduk Rintayati, Jenny Indrastoeti Siti Poerwanti}

Universitas Sebelas Maret

lindapradina26@gmail.com

\section{Article History}

accepted 09/07/2018

approved 01/08/2018

published 17/09/2018

\section{Keywords}

experimental skills, predict observe Explain, POE

\begin{abstract}
The objective of this research is to improve the experimental skills of $4^{\text {th }}$ grade students of SD N Surakarta year 2017/2018 through the application of Predict, Observe, Explain (POE) learning model in learning natural science.

This research is a classroom action research conducted in three cycles and each cycle consists of two meetings. The subjects of this research are teacher and fourth graders of SDN N Surakarta Year 2017/2018 consisting of 12 students. Data collection techniques used are observation, interview, and documentation. Data analysis technique used is interactive analysis model which has four components consisting of data collecting, data reduction, data display, and conclusion. Data validity test uses content validity and triangulation. Based on the results of research, it can be concluded that the application of Predict, Observe, Explain (POE) learning model can improve the experimental skills of $4^{\text {th }}$ grade students of SD N Surakarta Year 2017/2018.
\end{abstract}

Social, Humanities, and Education Studies (SHEs): Conference Series https://jurnal.uns.ac.id/shes

p-ISSN 2620-9284

e-ISSN 2620-9292 


\section{PENDAHULUAN}

IImu Pengetahuan Alam (IPA) merupakan salah satu mata pelajaran pokok dalam kurikulum pendidikan Indo-nesia yang diajarkan dari jenjang sekolah dasar hingga perguruan tinggi. Hal tersebut dilatarbelakangi karena pembelajaran IPA tidak hanya berpusat pada pemahaman suatu konsep saja, namun dapat memberikan pengalaman langsung kepada peserta didik sehingga mendorong peserta didik untuk memiliki pola pikir yang kritis, memiliki sikap ilmiah, dan menguasai berbagai keterampilan proses. Keterampilan proses sendiri mencakup beberapa komponen keterampilan yang saling terkait.

Permendikbud No. 22 tahun 2006 tentang standar isi menyebutkan bahwa muatan dalam pembelajaran IPA SD adalah peserta didik ditekankan untuk melakukan pengamatan langsung ter-hadap objek IPA menggunakan panca indera dan alat sederhana. Pembelajaran tersebut terpenuhi dalam rangkaian eksperimen. Penerapan keterampilan bereksperimen sendiri memiliki beberapa manfaat bagi siswa, yaitu: (1) membantu siswa untuk mengembangkan pikirannya, (2) memberikan kesempatan kepada siswa untuk melakukan penemuan, (3) meningkatkan daya ingat, (4) memberikan kepuasan intrinsik bagi peserta didik telah berhasil melakukan sesuatu, dan juga (5) membantu peserta didik untuk menguasai proses-proses sains (Dahar (1985), dalam Devi, 2010 : 29).

Pada kenyatannya, keterampilan bereksperimen yang dimiliki oleh siswa kelas IV SD N Surakarta masih rendah. Hal tersebut dibuktikan dengan hasil wawancara baik dengan siswa maupun dengan guru, hasil observasi, serta hasil tes pratindakan. Hasil observasi yang telah dilaksanakan diperoleh fakta bahwa: (1) pembelajaran IPA yang dilaksanakan masih berpusat pada ranah kognitif saja, (2) pelaksanaan kegiatan praktikum jarang dilakukan, walaupun di SD tersebut terdapat beberapa KIT IPA yang merupakan bantuan dari pemerintah, (3) siswa kurang bisa memahami pembelajaran dengan jelas. Hasil wawancara dengan guru yang dilaksanakan pada tanggal 15 Desember 2017 diperoleh hasil : (1) IPA merupakan salah satu mata pelajaran yang dikeluhkan oleh guru, khususnya pada aspek keterampilan, (2) pembelajaran menggunakan praktikum masih jarang dilaksanakan, dan (3) pembelajaran masih berpusat pada buku (text-book oriented).

Hasil wawancara dengan guru tersebut sejalan dengan hasil wawancara dengan siswa yang dilaksanakan pada tanggal yang sama dengan hasil: (1) IPA merupakan salah satu mata pelajaran yang dianggap sulit dikarenakan tidak dapat langsung dipahami dengan sekali penjelasan, dan (2) pembelajaran yang dilaksanakan belum mengikutsertakan siswa dalam kegiatan observasi/ praktikum. Hasil yang telah didapatkan dari kegiatan observasi dan wawancara kemudian ditindaklanjuti dengan pelaksanaan tes pratindakan yang dilaksanakan pada 16 Desember 2017 dengan hasil $8,33 \%$ atau 1 dari 12 siswa masuk dalam kategori tidak terampil, 58,33\% siswa atau 7 siswa dari 12 siswa tergolong dalam kategori kurang terampil dan 33,33\% siswa atau 4 siswa dari 12 siswa tergolong dalam kategori cukup terampil (KKM 80).

Terkait dengan belum optimalnya keterampilan bereksperimen yang dimiliki oleh siswa kelas IV SD N Surakarta, maka saya menerapkan model pembelajaran Predict, Observe, Explain (POE) untuk meningkatkan keterampilan bereksperimen dalam pembelajaran IPA.

Model pembelajaran POE adalah model pembelajaran yang membuat siswa aktif karena pembelajaran POE dapat meminimalisir peran dari seorang guru dan memberikan banyak keleluasaan kepada siswa untuk membuat penemuan. Dengan demikian, kelebihan dari POE salah satunya adalah mampu mengetahui keterampilan proses belajar menjadi lebih hidup, karena siswa terlibat secara langsung dalam menemukan konsep atau suatu keterampilan proses belajar. (Nurmalasari, Jayadinata, \& Maulana, 2016). 
Anisa (2013) menjelaskan jurnal yang berjudul "The Grade 1 Student's Mental Model of Force and Motion Through Preditc-Observe-Explain (POE) Strategy", menyimpulkan bahwa pembelajaran dengan penerapan model POE diharapkan dapat membantu siswa untuk berlatih melakukan pengamatan secara langsung berdasarkan hasil prediksi yang telah dibuatnya, sehingga penerapan model POE diharapkan mampu meningkatkan keterampilan proses sains siswa.

Menurut Indrawati dan Wanwa (dalam Yupani, 2013) model POE merupakan suatu model pembelajaran dimana guru menggali pemahaman peserta didik dengan cara meminta mereka melaksanakan tiga tugas utama yaitu meramalkan, mengamati, dan memberikan penjelasan. Model POE bersifat konstruktivis karena siswa diberi kebebasan untuk memikirkan persoalan yang diajukan dan siswa mencoba membangun pengetahuannya lewat berpikir, praktik, dan mencari penjelasannya. Berdasarkan uraian diatas dapat diperoleh fakta bahwa pembelajaran dengan menerapkan model POE dapat meningkatkan keterampilan proses yang dimiliki oleh peserta didik. Hal tersebut didasarkan pada model POE sendiri merupakan suatu model pembelajaran yang memfasilitasi siswa untuk mengembangkan aktivitas fisik dan mental yang dimilikinya, yang mana siswa dapat memperoleh pengalaman belajar nyata melalui pembelajaran yang berbasis praktikum. Dengan demikian, penerapan model POE dalam pembelajaran dapat membantu siswa dalam meningkatkan keterampilan bereksperimen yang dimilikinya.

\section{METODE}

Penelitian ini dilaksanakan pada siswa kelas IV SD N Surakarta Tahun Ajaran 2017/2018. Waktu penelitian dimulai sejak bulan Desember 2017 sampai dengan bulan Juli 2018. Subjek dalam penelitian ini adalah siswa dan guru kelas IV SD N Surakarta Tahun Ajaran 2017/2018. Penelitian ini menggunakan pendekatan kualitatif jenis Penelitian Tindakan Kelas (PTK) dengan model siklus. Penelitian ini dilaksanakan menggunakan prosedur penelitian yang dilakukan melalui 3 siklus. Pada tiap siklusnya memiliki empat tahapan yaitu perencanaan, pelaksanaan, pengamatan, dan refleksi.

Data yang dikumpulkan dalam penelitian ini berupa data kuantitatif dan data kualitatif. Data kuantitatif meliputi nilai keterampilan bereksperimen siswa dalam pembelajaran IPA. Sedangkan data kualitatif meliputi hasil wawancara guru dan siswa, penilaian kinerja guru, dan hasil dokumentasi. Pengumpulan data dilaksanakan dengan teknik observasi, wawancara, dan dokumentasi

Uji validitas data menggunakan validitas isi yang berupa lembar instrumen penelitian keterampilan bereksperimen, pedoman wawancara guru dan siswa, serta pedoman observasi. Selain itu, uji validitas menggunakan teknik triangulasi meliputi triangulasi sumber dan triangulasi teknik. Teknik analisis data dalam penelitian ini menggunakan model analisis interaktif yaitu meliputi reduksi data, penyajian data, dan kesimpulan.

\section{HASIL DAN PEMBAHASAN}

Berdasarkan data yang diperoleh dari hasil wawancara, observasi, dan tes pratindakan menunjukkan bahwa tingkat keterampilan bereksperimen siswa kelas IV SD N Surakarta masih rendah. Hasil skor rata-rata setiap aspek keterampilan bereksperimen tertera pada Tabel 1 berikut: 
Tabel 1. Skor Rata-rata Setiap Aspek Keterampilan Bereksperimen Pratindakan

\begin{tabular}{|c|c|c|c|}
\hline No & Aspek Penilaian & $\begin{array}{c}\text { Nilai } \\
\text { Pratindakan }\end{array}$ & Keterangan \\
\hline 1. & $\begin{array}{lr}\text { Menyiapkan } & \text { Alat dan } \\
\text { Bahan } & \text { yang } \\
\text { Dibutuhkan } & \end{array}$ & 48 & Kurang Terampil \\
\hline 2. & $\begin{array}{l}\text { Melaksanakan } \\
\text { Kegiatan } \\
\text { Bereksperimen }\end{array}$ & 41 & Kurang Terampil \\
\hline 3. & $\begin{array}{l}\text { Merumuskan } \\
\text { Kesimpulan }\end{array}$ & 45 & Kurang Terampil \\
\hline 4. & $\begin{array}{l}\text { Mengomunika-sikan } \\
\text { Hasil Eksperimen } \\
\text { Rata-Rata }\end{array}$ & $\begin{array}{c}47 \\
45,25 \\
\end{array}$ & $\begin{array}{l}\text { Kurang Terampil } \\
\text { Kurang Terampil }\end{array}$ \\
\hline
\end{tabular}

Berdasarkan Tabel 1 dapat diketahui bahwa aspek menyiapkan alat dan bahan dalam kategori kurang terampil,aspek melaksanakan kegiatan bereksperimen dalam kategori kurang terampil, aspek merumuskan kesimpulan dalam kategori kurang terampil, dan aspek mengomunikasikan hasil eksperimen dalam kategori kurang terampil. Hasil tersebut membuktikan bahwa keterampilan bereksperimen siswa masih perlu ditingkatkan dan belum mencapai kategori terampil atau dengan $\geq 80$. Hasil observasi keterampilan bereksperimen dapat dibuat distribusi frekuensi keterampilan bereksperimen pratindakan pada Tabel 2 berikut:

Tabel 2. Distribusi Frekuensi Keterampilan Bereksperimen Pratindakan

\begin{tabular}{ccccc}
\hline \multirow{2}{*}{ No } & Nilai & \multirow{2}{*}{ Frekuensi } & \multicolumn{2}{c}{ Persentase \% } \\
& Kumulatif & Relatif \\
\hline 1. & 35 & 1 & 8,33 & 8,33 \\
2. & 40 & 2 & 16,67 & 25 \\
3. & 45 & 4 & 33,34 & 58,33 \\
4. & 50 & 1 & 8,33 & 66,67 \\
5. & 65 & 1 & 8,33 & 75 \\
6. & 70 & 3 & 25 & 100 \\
Jumlah & $\mathbf{1 2}$ & $\mathbf{1 0 0}$ & $\mathbf{1 0 0}$ \\
\multicolumn{5}{c}{ Nilai Tertinggi 70 } \\
Nilai Terendah 35 \\
\multicolumn{5}{c}{ Ketercapaian Indikator Kinerja $\geq \mathbf{8 0} \%$} \\
\hline
\end{tabular}

Berdasarkan Tabel 2, dapat didapatkan data mengenai keterampilan bereksperimen siswa pratindakan yaitu dari 12 siswa belum terdapat siswa atau 0\% dengan kategori terampil, 4 siswa atau 33,33\% termasuk dalam kategori cukup terampil, 7 siswa atau 58,33\% termasuk dalam kategori kurang terampil, dan 1 siswa atau $8,33 \%$ yang termasuk dalam kategori kurang terampil. Data tersebut menandakan perlu adanya pelaksanaan tindakan pada siklus I. Pada siklus I dilaksanakan tindakan terhadap siswa kelas IV SD N Surakarta berupa penggunaan model POE dalam pembelajaran IPA. Siklus I terdiri dari dua pertemuan, yaitu pertemuan 1 dan 2 . Hasil observasi keterampilan bereksperimen siklus I pertemuan 1 didapatkan skor rata-rata setiap aspek keterampilan bereksperimen yang terdapat dalam Tabel 3 berikut: 
Tabel 3. Skor Rata-rata Setiap Aspek Keterampilan Bereksperimen Siklus I Pertemuan 1

\begin{tabular}{clcc}
\hline No & \multicolumn{1}{c}{$\begin{array}{c}\text { Aspek } \\
\text { Penilaian }\end{array}$} & $\begin{array}{c}\text { Nilai Siklus I } \\
\text { Pertemuan 1 }\end{array}$ & Ket \\
\hline 1. & $\begin{array}{l}\text { Menyiapkan Alat dan } \\
\text { Bahan yang } \\
\text { Dibutuhkan } \\
\text { Melaksanakan } \\
\text { Kegiatan }\end{array}$ & 54 & Kurang Terampil \\
Bereksperimen & 65 & Cukup Terampil \\
3. $\begin{array}{l}\text { Merumuskan } \\
\text { Kesimpulan } \\
\text { Mengomunika-sikan }\end{array}$ & 60 & Cukup Terampil \\
& $\begin{array}{l}\text { Hasil Eksperimen } \\
\text { Rata-Rata }\end{array}$ & 60 & Cukup Terampil \\
\hline & 59 & Kurang Terampil \\
\hline
\end{tabular}

Berdasarkan Tabel 3 dapat diketahui bahwa skor rata-rata bahwa keempat aspek keterampilan bereksperimen yaitu menyiapkan alat dan bahan yang dibutuhkan, melaksanakan kegiatan bereksperimen, merumuskan kesimpulan, dan mengomunikasikan hasil eksperimen pada siklus I pertemuan 1 berada dalam kategori kurang terampil. Selanjutnya, hasil observasi keterampilan bereksperimen pada siklus I pertemuan 1 dapat dibuat distribusi frekuensi keterampilan bereksperimen siklus I pertemuan 1 pada Tabel 4 berikut:

Tabel 4. Distribusi Frekuensi Keterampilan Bereks-perimen Siklus I Pertemuan 1

\begin{tabular}{lcccc}
\hline \multirow{2}{*}{ No } & Nilai & Frekuensi & \multicolumn{2}{c}{ Persentase \% } \\
& & & Kumulatif & Relatif \\
\hline 1. & 50 & 4 & 33,34 & 33,34 \\
2. & 55 & 1 & 8,33 & 41,67 \\
3. & 60 & 4 & 33,34 & 75,01 \\
4. & 65 & 1 & 8,33 & 83,44 \\
5. & 80 & 1 & 8,33 & 91,67 \\
6. & 90 & 1 & 8,33 & 100 \\
Jumlah & $\mathbf{1 2}$ & $\mathbf{1 0 0}$ & $\mathbf{1 0 0}$ \\
Nilai Tertinggi 90 & & \\
Nilai Terendah 50 & & \\
\multicolumn{3}{l}{ Ketercapaian Indikator Kinerja $\geq \mathbf{8 0} \% \mathbf{( 1 6 , 6 7 \% )}$} \\
\hline
\end{tabular}

Berdasarkan Tabel 4 di atas, didapatkan data mengenai keterampilan bereksperimen siswa siklus I pertemuan 1 yaitu dari 12 siswa tidak terdapat siswa atau $0 \%$ dalam kategori tidak terampil, 5 siswa atau $41,67 \%$ dalam kategori kurang terampil, 5 siswa atau 41,67\% dalam kategori cukup terampil, dan 2 siswa atau 16,67\% dalam kategori terampil. Data nilai keterampilan bereksperimen siklus I pertemuan 1 menunjukkan belum mencapai indikator kinerja dalam penelitian ini.

Kemudian data observasi keterampilan bereksperimen siklus I pertemuan 2 didapatkan skor rata-rata pada setiap aspek keterampilan bereksperimen pada Tabel 5 berikut: 
Berdasarkan Tabel 9 dapat diketahui bahwa skor rata-rata bahwa keempat aspek keterampilan bereksperimen yaitu menyiapkan alat dan bahan yang dibutuhkan, melaksanakan kegiatan bereksperimen, merumuskan kesimpulan, dan mengomunikasikan hasil eksperimen pada siklus II pertemuan 2 berada dalam kategori terampil. Selanjutnya, hasil observasi keterampilan bereksperimen pada siklus II pertemuan 2 dapat dibuat distribusi frekuensi keterampilan bereksperimen siklus II pertemuan 2 pada Tabel 10 berikut:

Tabel 10. Distribusi Frekuensi Keterampilan Bereksperimen Siklus II Pertemuan 2

\begin{tabular}{|c|c|c|c|c|}
\hline \multirow{2}{*}{ No } & \multirow{2}{*}{ Nilai } & \multirow{2}{*}{ Frekuensi } & \multicolumn{2}{|c|}{ Persentase \% } \\
\hline & & & Kumulatif & Relatif \\
\hline 1. & 55 & 2 & 16,67 & 16,67 \\
\hline 2. & 70 & 1 & 8,33 & 25 \\
\hline 3. & 80 & 2 & 16,67 & 41,67 \\
\hline 4. & 85 & 1 & 8,33 & 50 \\
\hline 5. & 90 & 1 & 8,33 & 58,33 \\
\hline 6. & 95 & 5 & 41,67 & 100 \\
\hline Jum & & 12 & 100 & 100 \\
\hline \multicolumn{5}{|c|}{ Nilai Tertinggi 95} \\
\hline \multicolumn{5}{|c|}{ Nilai Terendah 55} \\
\hline \multicolumn{5}{|c|}{ Ketercapaian Indikator Kinerja $\geq 80 \%(75 \%)$} \\
\hline
\end{tabular}

Berdasarkan Tabel 10 di atas, didapatkan data mengenai keterampilan bereksperimen siswa siklus II pertemuan 2 yaitu dari 12 siswa tidak terdapat siswa atau $0 \%$ dalam kategori tidak terampil dan kurang terampil, 3 siswa atau $25 \%$ dalam kategori cukup terampil, dan 9 siswa atau 75\% dalam kategori terampil. Data nilai keterampilan bereksperimen siklus II pertemuan 2 menunjukkan belum mencapai indikator kinerja dalam penelitian ini sehingga perlu dilanjutkan pada siklus III dengan harapan dapat meningkatan indikator kinerja penelitian yang telah ditentukan.

Hasil observasi keterampilan bereksperimen pada siklus III pertemuan I didapatkan skor rata-rata setiap aspek keterampilan bereksperimen yang tertera pada Tabel 11 berikut:

Tabel 11. Skor Rata-rata Setiap Aspek Keterampilan Bereksperimen Siklus III Pertemuan 1

\begin{tabular}{llcc}
\hline No & \multicolumn{1}{c}{ Aspek Penilaian } & $\begin{array}{c}\text { Nilai Siklus III } \\
\text { Pertemuan 1 }\end{array}$ & Ket \\
\hline 1. & $\begin{array}{l}\text { Menyiapkan Alat dan } \\
\text { Bahan yang Dibutuhkan } \\
\text { Melaksanakan Kegiatan }\end{array}$ & 77 & Cukup Terampil \\
2. & 94 & Terampil \\
3er-eksperimen & $\begin{array}{l}\text { Merumuskan } \\
\text { Kesimpulan } \\
\text { Mengomunikasi-kan } \\
\text { Hasil Eks-perimen } \\
\text { Rata-Rata }\end{array}$ & 89 & Terampil \\
\hline & 56 & Kurang Terampil \\
\hline
\end{tabular}

Berdasarkan Tabel 11 dapat diketahui bahwa skor rata-rata bahwa keempat aspek keterampilan bereksperimen yaitu menyiapkan alat dan bahan yang dibutuhkan, melaksanakan kegiatan bereksperimen, merumuskan kesimpulan, dan mengomunikasikan hasil eksperimen pada siklus III pertemuan 1 berada dalam kategori terampil. Selanjutnya, hasil observasi keterampilan bereksperimen pada 
siklus III pertemuan 1 dapat dibuat distribusi frekuensi keterampilan bereksperimen siklus III pertemuan 1 pada Tabel 12 berikut:

Tabel 12. Distribusi Frekuensi Keterampilan Bereks-perimen Siklus III Pertemuan 1

\begin{tabular}{lcccc}
\hline \multirow{2}{*}{ No } & Nilai & \multirow{2}{*}{ Frekuensi } & \multicolumn{2}{c}{ Persentase \% } \\
& & Kumulatif & Relatif \\
\hline 1. & 60 & 1 & 8,33 & 8,33 \\
2. & 75 & 1 & 8,33 & 16,67 \\
3. & 80 & 5 & 41,67 & 58,33 \\
4. & 85 & 1 & 8,33 & 66,66 \\
5. & 90 & 3 & 25 & 91,66 \\
6. & 95 & 1 & 8,33 & 100 \\
Jumlah & $\mathbf{1 2}$ & $\mathbf{1 0 0}$ & $\mathbf{1 0 0}$ \\
Nilai Tertinggi 95 & \multicolumn{3}{l}{} \\
Nilai Terendah 60 \\
\multicolumn{5}{l}{ Ketercapaian Indikator Kinerja $\leq \mathbf{8 0 \%}(\mathbf{8 3 , 3 3 \% )}$}
\end{tabular}

Berdasarkan Tabel 12 di atas, didapatkan data mengenai keterampilan bereksperimen siswa siklus III pertemuan 1 yaitu dari 12 siswa tidak terdapat siswa atau $0 \%$ dalam kategori tidak terampil dan kurang terampil, 2 siswa atau 16,67\% dalam kategori cukup terampil, dan 10 siswa atau $83,33 \%$ dalam kategori terampil.Selanjutnya, hasil observasi keterampilan bereksperimen pada siklus III pertemuan 2 dapat dibuat distribusi frekuensi keterampilan bereksperimen siklus III pertemuan 2 pada Tabel 13 berikut:

Tabel 13. Skor Rata-rata Setiap Aspek Keterampilan Bereksperimen Siklus III Pertemuan 2

\begin{tabular}{llcc} 
No & Aspek Penilaian & $\begin{array}{c}\text { Nilai Siklus III } \\
\text { Pertemuan 2 }\end{array}$ & Ket \\
\hline 1. & $\begin{array}{l}\text { Menyiapkan Alat dan } \\
\text { Bahan yang }\end{array}$ & 85 & Te-ram-pil \\
Dibutuhkan & $\begin{array}{l}\text { Melaksanakan } \\
\text { Kegiatan } \\
\text { eksperimen }\end{array}$ & 97 & Te-ram-pil \\
3. Ber- & $\begin{array}{l}\text { Merumuskan } \\
\text { Kesimpulan } \\
\text { Mengomuni-kasikan }\end{array}$ & 89 & Te-ram-pil \\
$\begin{array}{l}\text { Hasil Eksperimen } \\
\text { Rata-Rata }\end{array}$ & $\mathbf{8 8 , 5}$ & Te-ram-pil \\
\hline
\end{tabular}

Berdasarkan Tabel 13 dapat diketahui bahwa skor rata-rata bahwa keempat aspek keterampilan ber-eksperimen yaitu menyiapkan alat dan bahan yang dibutuhkan, melaksanakan kegiatan bereksperimen, merumuskan kesimpulan, dan mengomunikasikan hasil eksperimen pada siklus III pertemuan 2 berada dalam kategori terampil. Selanjutnya, hasil observasi keterampilan bereksperimen pada siklus III pertemuan 2 dapat dibuat distribusi frekuensi keterampilan bereksperimen siklus III pertemuan 2 pada Tabel 14 berikut: 
Hal tersebut dibuktikan dengan adanya peningkatan nilai keterampilan bereksperimen siswa mulai dari pratindakan sampai dengan siklus III pertemuan 2.

\section{SIMPULAN}

Berdasarkan pada hasil penelitian yang telah peneliti laksanakan selama tiga siklus dengan menerapkan model pembelajaran POE pada pembelajaran IPA di kelas IV SD N Surakarta, dapat diketahui bahwa penggunaan model pembelajaran Predict, Observe, Explain (POE) dalam pembelajaran IPA dapat meningkatkan keterampilan bereks-perimen siswa kelas IV SD N Surakarta Tahun Ajaran 2017/2018. Hal ini ditunjukkan dengan peningkatan hasil observasi keterampilan bereksperimen siswa yang terdiri dari empat keterampilan bereksperimen yaitu menyiapkan alat dan bahan yang dibutuhkan, melaksanakan kegiatan bereksperimen, merumuskan kesimpulan, dan mengomunikasikan hasil eksperimen.

Peningkatan tersebut dapat terlihat dari peningkatan jumlah siswa yang termasuk dalam kategori terampil. Jumlah siswa yang masuk dalam kategori terampil saat pratindakan adalah 0 siswa, pada siklus I pertemuan 1 siswa yang masuk dalam kategori terampil adalah 2 siswa atau 16,67\%, siklus I pertemuan 2 siswa yang masuk kategori terampil adalah 3 siswa atau 33,33\%. Siklus II pertemuan 1 siswa yang masuk dalam kategori terampil sebanyak 4 siswa atau 33,33\%, pada siklus II pertemuan 2 sebanyak 8 siswa atau $75 \%$. Siklus III pertemuan 1 mencatat jumlah siswa yang masuk kategori terampil sebanyak 10 siswa atau 83,33\%, dan pada siklus III pertemuan 2 jumlah siswa yang masuk dalam kategori terampil sebanyak 11 siswa atau $91,67 \%$.

\section{DAFTAR PUSTAKA}

Anisa. (2013). Pengaruh Model Pembelajaran POE (Predict, Observe, and Explaination) dan Sikap IImiah Terhadap Prestasi Belajar Siswa pada Materi Asam, Basa, dan Garam Kelas VII Semester 1 SMP N 1 Jaten Tahun Pelajaran 2012/2013. Jurnal Pendidikan Kimia (JPK), ISSN 2337-9995, 16-23.

BSNP. (2006). Permendikbud Nomor 22 Tahun 2006 Tentang Standar Isi Nasional Pendidikan. Jakarta: Kementrian Pendidikan Nasional. Diperoleh 26 Desember 2017 diakses pada http://bnsp-indonesia.org/id/wp-content/uploads/isi/SDMl.zip

Devi, P. K. (2010). Keterampilan Proses dalam Pembelajaran IPA. Jakarta : PPPKT IPA.

Hidayah, Y. (2018). Pengaruh Model Pembelajaran POE (Predict-ObserveExplain)Terhadap Keterampilan Proses Belajar Fisika Pokok Bahasan Suhu dan Kalor. Indonesian Journal of Science and Mathematics Education, E-ISSN: 2615-8639, 01 (1).

Pujiyati, S. (2016). Penerapan Model POE (Predict, Observe, and Explain) Berbasis Media Realia untuk Meningkatkan Pemahaman Konsep Energi Panas dan Bunyi. Jurnal Didaktika Dwija Indria, 4 (4).

Yupani, Garmiah, Mahadewi. (2013). Pengaruh Model Pembelajaran Predict-ObserveExplain (POE) Berbantuan Materi Kearifan Lokal Terhadap Hasil Belajar IPA Siswa Kelas IV. Singaraja : Undiksha.

Liew, C. -w., \& Treagust, D. F. (2009). The Effectiveness of Predict-Observe-Explain Tasks in Diagnosing Students' Understanding of Science and in Identifying Their Levels of Acheivement. Science and Mathematics Education Center, 3. 